\title{
IMPLEMENTASI KEBIJAKAN PENYIANGAN KOLEKSI DI UPT PERPUSTAKAAN UNIVERSITAS MUHAMMADIYAH MATARAM
}

\author{
Ridwan', Rohana ${ }^{2}$ \\ 'Prodi DIII Perpustakaan, Universitas Muhammadiyah Mataram \\ 2Prodi DIII Perpustakaan, Universitas Muhammadiyah Mataram \\ ridwanr320@gmail.com
}

INFO ARTIKEL
Riwayat Artikel:
Diterima: $28-02-2020$
Disetujui: 09-03-2020

\section{Kata Kunci:}

1. Kebijakan

2. Penyiangan

3. Koleksi

\section{A. PENDAhuluan}

Perpustakaan adalah perpaduan antara manusia, tempat fasilitas dan informasi. Dikatakan perpaduan , karena satu dengan yang lainnya saling bergantungan. Manusia, yaitu pengelolah dan pemakainya, tempat dan fasilitas merupakan sarana yang digunakan manusia untuk melakukan transaksi informasi, sementara informasi bisa berupa buku, jurnal, majalah, koran dan bahan pustaka lainnya adalah bahan-bahan yang disajikan di perpustakaan (Almah, 2017:2).

Sehubungan dengan hal tersebut, informasi yang dikumpulkan dan diolah harus sesuai dengan tujuan perpustakaan serta disesuaikan dengan lingkungan institusi atau perguruan tinggi yang menaungi perpustakaan tersebut, dan sikap pemustaka akan kebutuhan informasinya. Kebutuhan informasi pemustka sangat beragam dan kebutuhan tersebut banyak dipengaruhi oleh latar belakang pendidikan dan sosial budaya masyarakat. Untuk dapat menjadikan perpustakaan sebagai jantunya perguruan tinggi, maka perpustakaan harus dapat dijadikan sebagai pusat informasi sekaligus bermanfaaat bagi civitas akademika serta mendukung program perguruan tinggi tentu bukan merupakan tugas yang ringan (Sri Rohayanti Zulaikha, :42) terutama dalam hal penyiangan (weeding) koleksi perpustakaan. 
Kebutuhan pemustaka yang meningkat serta pengembangan koleksi perpustakaan yang dilakukan secara terus menerus menyebabkan makin bertambahnya koleksi yang ada di perpustakaan sehingga akan menyebabkan penumpukan koleksi di rak, selain itu juga semakin banyaknya koleksi di rak akan rentang terjadi kerusakan terhadap bahan pustaka, seperti gangguan dari binatang (serangga dan rayap) dan juga disebabkan oleh kondisi alam (basah, dan lembab).

Dengan demikian penyiangan (weeding) sebagai salah satu upaya pelestarian bahan pustaka agar lebih awet, bisa dipakai lebih lama dan bisa menjangkau lebih banyak pemustaka dalam penggunaaan keleksi perpustakaan.

Pentingnya kegiatan penyiangan koleksi (weeding) yang dilakukan pihak perpustakaan menurut Sujana (2009:31) bahwa tidak mungkin bagi sebuah perpustakaan untuk menyimpan semua koleksi yang telah yang telah diterbitkan di dunia, oleh karena itu sebesar apapun ruang perpustakaan, seberapa besarpun dananya, pustakawan harus mengelola koleksi dengan kebik dan penyiangan merupakan salah satu cara untuk menjaga agar koleksi yang dibutuhkan pemustaka dapat diakses dengan mudah dan cepat, tanpa dikacaukan oleh koleksi yang tidak terpakai lagi.

Penyiangan bahan pustaka (weeding) adalah upaya mengeluarkan koleksi dari susunan rak karena tidak diminati terlalu banyak eksemplar, telah ada edisi terbaru maupun koleksi itu tidak relevan. Koleksi yang dikelurkan ini dapat dihibahkan keperpustakaan lain, atau dimusnahkan (Maunglib, 2010).

Kegitan penyiangan (weeding) juga merupakan salah satu kegiatan dari perawatan koleksi yaitu mengeluarkan atau menarik bahan pustaka dari rak, disebkan karena suatudan lain hal bahan tersebut tidak bermanfaat lagi bagi pemustaka, bahan tersebut dikeluarkan dari rak perpustakaan agar tidak memenuhi ruangan yang semestinya diisi dengan koleksi yang lebih terkini (Almah, 2012:151).

Berdasarkan peraturan pemerintah republic Indonesia nomor 24 tahun 2014 tentang pelaksanaan Undang-Undang nomr 43 tahun 2007 tentang perpustakaan pasal 14 ayat 3, mengenai kebijakan pengembangan koleksi, pengadaan, pengolahan, dan penyiangan bahan perpustakaan.

Dilihat dari aturan pemerintah di atas bahwa bahan pustaka yang dikelola di perpustakaan sesuai dengan kebijakan pengembangan koleksi mencakup pengadaan, pengolahan, dan penyiangan koleksi perpustakaan.

Selain itu penyiangan koleksi perpustkaan juga diatur dalam standar nasional Indonesia (SNI) 7330:2009 menyatakan banya penyiangan koleksi adalah kegiatan mengeluarkan materi perpustakaan yang sudah tidak dipakai lagi dari koleksi. Dalam penyiangan koleksi harus mellihat terlebih dahulu apakah layak untuk disiangi berdarsarkan criteria yang ditetapkan.

Adapun tujuan dari penyiangan asalah untuk memperoleh tambahan tempat (shelf space) untuk koleksi baru, dan membuat koleksi lebih bisa dimanfaatkan sebagai sumber informasi yang relevan, akurat up to date maupun terlihat menarik, memberikan kemudahan kepada pemustaka dan memungkinkan pustakawan untuk mengelola koleksi lebih efektif dan efisien.

Sebagai perpustakaan perguruan tinggi yang memiliki bahan pustaka yang beragam dan jumlah koleksi yang cukup banyak, perpustakan Universitas Muhammadiyah Mataram telah melakukan pengembangan koleksi yaitu penyiangan (weeding) sebagai salah satu bentuk upaya pelestarian bahan pustaka. Kegiatan yang dilakukan, disesuaikan dengan keragaman maupun jenis bahan pustaka yang tersedia di perpustakaan Universitas Muhammadiyah Mataram adalah bahan pustaka tercetak, seperti buku, majalah, surat kabar, jurnal, skripsi dan lain-lain, 
dan bahan pustaka non cetak (koleksi audio visual) seperti kaset, CD, VCD, dan DVD.

UPT Perpustakaan Universitas Muhammadiyah Mataram memiliki visi yaitu mengembangkan perpustakaan sebagai pusat kegiatan akademik yang unggul bebasis keilmuan dan keislaman. Untuk mewujudkan visi tersebut, maka perlu adanya penyiangan (weeding) bahan pustaka.

Oleh karena itu dalam prosedur penyiangan (weeding) bahan pustaka yang dilakukan oleh UPT Perpustakaan Universitas Muhammadiyah Mataram sangat menarik untuk dikaji dan diteliti, agar kegiatan yang dilakukan terkait pernyiangan tersebut dapat ditemukan kendala, tantangan maupun kekurangan agar kedepanya bisa diperbaiki untuk memperoleh hasil yang diinginkan.

\section{B. RUMUSAN MASALAH}

Berdasarkan latar belakang di atas, dapat di rumuskan masalah sebagai berikut :

1. Bagaiman penerapan kebijakan penyiangan koleksi di UPT Perpustakaan Muhammadiyah Mataram?

2. Bagaimana kriteria penyiangan koleksi di UPT Perpustakaan Universitas Muhammadiyah Mataram?

3. Apa kendala dalam penerapan kebijakan penyiangan koleksi oleh UPT Perpustakaan Universitas Muhammadiyah Mataram?

\section{DESKRIPSI FOKUS PENELITIAN}

Berdasarkan latar belakang di atas, penulis membatasi deskripsi fokus untuk memudahkan proses pelaksanaan penelitian. Adapun deskripsi fokus yang akan dibahas dalam penelitian ini dalah dikhususkan terhadap kebijakan Penyiangan Koleksi di UPT Pepustakaan Universitas Muhammadiyah Mataram, antara lain sebagai berikut:

1. Kebijakan penyiangan koleksi mencakup proses dan tindakan yang tepat dalam melakukan kegiatan penyiangan.

2. Kriteria atau pemilihan koleksi yang akan disiangi.
3. Kendala yang dihadapi dalam penerapan kebijakan kegiatan penyiangan koleksi.

\section{LANDASAN TEORI}

\section{Pengertian Kebijakan}

Kebijakan (policy) merupakan landasan atau pedoman untuk menyusun suatu kegiatan, agar kegiatan tersebut terarah. Ada beberapa kebijakan yang perlu diperhatikan, adapun kriteria penyiangan koleksi menurut jenis bahan pustaka yang disiangi yaitu sebagai berikut:

a. Buku (monograf)

Dalam melakukan penyiangan bahan pustaka yang berupa buku atau monografi () yang perlu diperhatikan adalah sebagai berikut:

1) Bidang kajian. Bidang kajian yang sudah tidak sesuai dengan kebijakan instansi dan tujuan perpustakaan sebagaiknya diasingkan.

2) Usia atau umur koleksi. Dapat dipertimbangkan agar koleksi tersebut dapat diganti dengan koleksi baru.

3) Cakupan duplikasi. Jumlah koleksi yang memiliki eksemplar yang banyak dalam jajaran rak sebaiknya dikurangi dan disisihkan ke tempat lain.

4) Sumberr alternatif. Dengan adanya kerjasama antar perpustakaan maka koleksi yang kurang bermanfaat dapat diakses dengan mengakses kepada perpustakaan lain yang memiliki informasi yang dibutuhkan.

5) Kondisi fisik. Buku-buku yang sobek, lapuk dan jidanya rusak sebaiknya di siangai (weeding) untuk dilakukan perbaikan.

6) Tingkat perlakukan. Buku-buku yang berisi prinsip-prinsip dasar mempunyai manfaat yang lebih tinggi dan bersifat lama jika dibandingkan dengan buku-buku-buku yang bersifat manual yang akan cepat out of 
date sejalan dengan perkembangan teknologi.

7) Kepentingan pengarang. Pengarang yang lebih menguasai tentang suatu subyek dalam ilmu tersebut, sebaiknya dipertahankan. Namun apabila terpaksa harus dikeluarkan, maka harus ditempatkan pada tempat yang mudah untuk ditelusuri kembali.

8) Bahasa. Buku yang diterbitkan dalam bahasa inggris biasanya lebih lama umur pemakaiannya, jika dibandingkan dengan buku yang diterbitkan dalam bahasa lain.

b. Serial

Berbeda dengan kebijakan penyiangan bahan pustaka yang berupa buku atau monografi, penyiangan bahan pustaka yang berupa serial memiliki kebijakan tersendiri (Yunus Winoto, ) yaitu, sebagai berikut:

1) Penerbit. Untuk penerbit serial yang prestisius dengan menerbitkan terbitan untuk obyek kajian kepada masyarakat luas, hendaknya dipertahankan.

2) Cakupan indeks. Majalah yang menpunyai cakupan indeks dan abstrak lebih bagus hendaknhya menjadi bahan pertimbangan jika dibandingkan dengan majalah yang tanpa disertai indeks dan abstraks.

3) Versi diganti, saat ini sudah banyak dijumpai majalah versi mikro, sehingga terbitan berseri yang sudah ada penggantinya ini dapat disisihkan untuk disiangi.

4) Usia. Untuk terbitan berseri ini dilakukan penyisihan, maka keseluruhan volume saja atau dengan beberapa nomor saja.

5) Bahasa. Bahasa yang digunakan akan turut menjadi faktor yang perlu dipertimbangkan dalam menyiangi koleksi serial ini.

Sehubungan dengan penjelasan di atas, kriteria penyiangan untuk koleksi majalah
Menurut Lasa HS () "penyortiran majalah dilakukan untuk judul-judul majalah yang telah banyak dibaca oleh pemustaka karena telah cukup waktu dipajang, maka hendaknya segera diambil. Kemudian majalah-majalah untuk sementara waktu disimpan dulu dalam lemari, gudang, atau rak khusus diurutkan judulnya”.

c. Bahan Audio Visual

Menurut Qolbyubi semua bahan audio visual yang rusak atau cacat menjadi calon untuk disiangi. Keputusan dibuat per judul oleh Kepala bagian audio visual. Frekuensi penggunaan dan kerusakan menjadi factor penting dalam keputusan (Masridah, 2009).

d. Bahan terbitan pemerintah

Edisi-edisi terbitan pemerintah yang ada dalam koleksi terbitan pemerintah (government Document Collection) yang menjadi kadaluarsa dengan adanya edisi baru menjadi calon untuk ditarik. Keputusan akhir dibuat perjudul oleh pustakawan yang mengelola koleksi tersebut (Yunus Winoto, 2004: 11)

e. Bahan rujukan

Bagian rujukan telah menetapkan kebijakan khusus bagi banyak sumber rujukan yang secara periodik menjadi kadaluarsa karena telah ada revisi atau edisi terbaru sebagai penggantinya. Keputusan untuk menarik judul-judul ini dan untuk merevisi kebijakan penyiangan dibuat oleh kepala bagian rujukan, yang berkonsultasi dengan pustakawan pengembangan koleksi (Yunus Winoto, 2004: 11)

\section{Pengertian Penyiangan (weeding)}

Penyiangan adalah upaya memeriksa dan mengeluarkan koleksi perpustakaan untuk mengetahui koleksi yang tidak relevan lagi, terlalu banyak jumlah eksemplarnya, sudah ada edisi 
baru, atau oleksi itu termasuk terbitang yang dilarang.

Dalam Dictionary of library and Information Science (2014:69, menyatakan bahwa:

"Weeding the process of examining items in a library collection title by titleto identify for permanent with drawal those that meet preestablished weeding criteria, especially when space in the stacks limited. Public libreries usually weed routinely on the basic of circulation. In academic libraries, weeding is done less frequenly, usually only when the shelves become overcrowded, in anticipation of a move, or when a significant change occurs in curriculum, such as the elimination of a major. Weeding should be undertaken judiciously because out of print titles can be difficult to replace".

Pendapat diatas dapat diartikan dan dijelaskan sebagai berikut:

Penyiangan merupakan proses memeriksa item dalam sebuah judul untuk mengidentifikasi secara permanen dengan gambaran yang memenuhi kriteria penyiangan yang telah ditetapkan, ketika ruang di rak terbatas. Pustakawan biasanya melakukan penyiangan secara rutin pada bagian sirkulasi. Di perpustakaan akademik, penyiangan jarang dilakukan, biasanya hanya ketika rak buku telah penuh, untuk mengantisipasi pemindahan, atau ada perubahan kurikulum, sperti penghapusan beberapa mata kulia. Penyiangan harus dilakukan secara bijaksana karena judul yang di cetak tidak dapat diganti.

Sedangkan menurut Lasa Hs (2005:323) penyiangan (weeding) merupakan upaya mengeluarkan sejumlah eksemplar, sudah ada edisi baru, atau koleksi itu termasuk terbitan yang dilarang. Koleksi ini dapat ditukarkan dengan koleksi perpustakaan lain, dihadiaan, atau dihancurkan untuk pembuatan kertas lagi. Penyiangan merupaan bagian dari pengembangan koleksi perpustakaan yang merupakan bagian penting dalam mencapai tujuan perpustakaan.
Evan (2000:407) mengemukakan bahwa, penyiangan merupakan bagian integral dalam pengembangan koleksi.

Sehubungan dengan hal di atas Allen dalam Sugana (2011:16) menyatakan ahawa alas an suatu kolesi disiangi, antara lain, sebagai berikut:

a. Kebanyakan perpustakaan menghadapi kekurangan ruangan, jadi penting sekali menyimpan sumber daya terbaik di perpustakaan.

b. Sebuah perpustaaan harus tertata rapi agar pemustaka dengan mudah mendapata yang mereka cari.

c. Pemustaka menginginkan buku-buku yang antraktif.

d. Koleksi yang tidak disiangi seringkali berisi materi klise dan informasi yang kadaluarsa yang tidak dapat diterima, bukan materi yang dapat dipercaya, akurat, tidak bias, mutakhir yang di butuhkan pemustaka.

Koleksi secara berkala perlu disiangi, agar bahan pustaka yang sudah tidak sesuai dengan kebutuhan pemustaa dapat diganti dengan bahan pustaka yang baru. Pemilihan bahan pustaka yang dikeluarkan dari koleksi sebaiknya dilakukan oleh petugas perpustakaan dan ahlinya.

Kemudian bahan pustaka yang sudah disiangi dipisahkan, dipindahkan, dihibahkan, atau dimusnahkan. Keputusan tersebut berdasarkan pertimbangan kemutakhiran, kesesuaian dan kondisi fisik dokumen, adapun alasan pengeluaran bahan pustaka dari koleksi adalah bahan pustaka yang rusak dan tidak dapat diperbaiki, bahan pustaka yang isisnya tidak lengkap, bahan pustaka yang jumlah eksemplarnya terlalu banyak.

Berdasarkan uraian di atas dapat dinyatakan, bahawa penyiangan bahan pustaka adalah penyeleksian dan menyingkirkan bahan pustaka dari rak koleksi karena berbagai 
faktor.baik faktor fisik maupun faktor nilai bahan pustaka sperti bahan pustaka yang isinya tidak mutahir lagi, rusak, ada edisi baru, untuk menjaga agar nilai informasi koleksi yang dimiliki perpustakaan tersebut tetap up to date.

\section{Prosedur Penyiangan Koleksi (weeding)}

Yang tidak kalah pentingnya untuk dikaji adalah terkait masalah prosedur penyiangan koleksi. Prosedur adalah sebuah cara sistematis dan terpikir secara baik untuk mencapai tujuan; prinsip dan praktek-praktek pengajaran (Tim Reality, 2008:448). Dalam melakukan kegiatan penyiangan koleksi perpustakaan, ada beberapa prosedur yang harus dilakukan, antara lain sebagai berikut:

a. Pustakawan (bersama dengan pihak lain yang terkait) mengadakan pemilihan bahan pustaka yang perlu dikeluarkan dari rak koleksi berdasarkan pedoman penyiangan yang telah ditetapkan.

b. Pustakawan menyusun daftar koleksi yang akan dikeluarkan dari rak.

c. Buku-buku yang akan dikeluarkan dari rak, kartu katalognya harus diambil sebagai acuan penghapusan data koleksi di database sistem

d. Buku-buku yang akan dikelurkan diberi tanda "dikeluarkan dari rak perpustakaan" sebagai bukti bahwa buku tersebut bukan lagi milik perpustakaan.

e. Apabila bahan pustaka tersebut masih layak untuk digunakan (eksemplarnya terlalu banyak namun isis belum "out of date" dapat disisihkan untuk bahan penukaran atau hadiah.

f. Jikan koleksi tersebut dirasa masih banyak yang cari dan digunakan oleh pemustaka, maka koleksi tersebut di simpan digudang (weeding stock)

g. Untuk bahan pustaka yang akan dimusnahkan hendaknya memperhatikan peraturan yang berlaku berkaitan dengan penghapusan barang milik Negara, terutama untuk perpustakaan yang bernaung di bawah pemerintah.

\section{Kendala Penyiangan (weeding)}

Kegiatan penyiangan koleksi perpustakaan bukan hal yang mudah untuk dilakukan. Karena proses penyiangan memerlukan tahapan-tahapan dan pelaksanaan yang panjang, selain itu dalam pelaksanaannya terdapat kendala atau hambatan dari pihak pengelola perpustakaan itu sendiri. Berkaitan dengan hal tersebut penulis melihat beberapa kendala dalam pelaksanaan kegiatan penyiangan (Yunus Winoto, 2004:17), antara lain sebagai berikut:

a. Adanya kebanggaan terhadap koleksi (hambatan psikologis) sperti adanya perasaan tidak rela membuang bahan pustaka.

b. Masih adanya anggapan jumlah koleksi menentukan mutu. Jumlah koleksi dianggap akan menunjukkan kehebatan perpustakaan tanpa memperhatikan kondisi dan relevansi bahan pustaka tersebut dengan tujuan perpustakaan.

c. Adanya anggapan bahwa penyiangan berlawanan dengan tujuan pengadaan atau konsep pengembangan koleksi

d. Masih dijumpai prosedur yang rumit, terutama untuk koleksi yang ada diperpustakaan pemerintah, karena setiap pengeluaran barang harus dilakukan melalui prosedur yang membutuhkan waktu lama dan terkesan rumit.

Dalam buku yang berjudul less more than less, Donna J. Baumbach dan Linda L. Miller menyebutkan bahwa ada beberapa kendala dal weeding (2006). Antara lain sebagai berikut:

a. Rasa bangga terhadap sebuah koleksi

b. Pustakawan atau staf perpustakaan sebelumnya tidak melakukan weeding, sehingga malas untuk melakukannya.

c. Perasaan tidak suka membuang koleksi 
d. Lebih senang memberikan koleksi kepada perpustakaan lain atau orang lain dari pada membuangnya.

e. Koleksi yang banyak akan menunjang proses akreditasi, jadi koleksi tetap disimpan.

f. Rasa saying terhadap sebuah koleksi, hingga tidak akan membuang atau melakukan weeding hingga koleksi tersebut pantas untuk di musnahkan (benar-benar rusak)

g. Prinsip seseorang yang tidak akan pernah melakukan weeding

h. Jika weeding dilakukan orng akan menganggap bahwa hal tersebut membuang ilmu atau membuang penemuan dari seseorang dan membuang uang.

i. Tiak memiliki waktu cukup untuk melakukan weeding

j. Ketidak tahuan seseorang mengenai ilmu dan manfaat weeding, sehingga timbulrasa takut akan membuang koleksi yang harga atau seharusnya tidak dibuang.

\section{E. METODE PENELITIAN}

\section{Metode Penelitian}

Metode penelitian merupakan tatacara atau prosedur tentang bagaimana melaksanakan suatu penelitian yang sedang dilaksanakan Sugiyono (2009:6) mejelaskan bahwa metode penelitian adalah cara-cara ilmiah untuk mendapakan data yang valid, dengan tujuan dapat ditemukan, dan dibuktikan suatu penelitian tertentu sehingga pada gilirannya dapa digunakan untuk memahami, memecahkan, dan mengantisipasi masalah.

Jenis penelitian ini adalah penelitian deskripsi dengan pendekatan kualitatif, penelitian hanya mengembangkan konsep dan menghimpun fakta tetapi tidak melakukan pengujian hipotesis. Oleh sebab itu penelitian ini terbatas pada usaha mengungkapkan suatu keadaan peristiwa subjek atau objek penelitian pada saat sekarang berdasarkan pada fakta yang tampak atau sebagaimana adanya yang didukung oleh metode survey dengan observasi dan wawancara.

\section{Data dan Sumber Data}

Data dan sumber data yang digunakan dalam penelitian ini yaitu:

a. Data primer data yang diperoleh melalui wawancara dan pengamatan yang dilakukan secara langsung sebagai dasar utama melakukan interpretasi data. Adapun data yang diperoleh melalui wawancara dan pengamatan ini yaitu berupa hasil rekaman suara, serta hasil pengamatan baik berupa tulisan maupun gambar yang diperoleh ketika melakukan penelitian.

b. Data sekunder merupakan data yang diperoleh melalui studi kepustakaan seperti buku, jurnal, meupun dokumen perpustakaan lain yang berhubungan dengan penelitian.

\section{Proses Pengumpulan Data}

a. Kategori Informan

Dalam penelitian ini yang dimaksud dengan informan adalah orang yang dianggap mengetahui dengan baik terhadap masalah yang diteliti dan bersedia untuk member informasi kepada peneliti. Pemilihan informan didasarkan pada penarikan informan yang dilakukan dengan subjek berdasarkan kriteria spesifik dan tujuan (purposive)

Table 1 Identifikasi Informan

\begin{tabular}{|c|c|c|}
\hline No. & Kode & Jabatan \\
\hline 1. & A (Informan 1) & Kepala Perpustakaan \\
\hline 2. & B (Informan 2) & Divisi Layanan \& Teknis \\
\hline 3. & C (Informan 3) & Koorditor Pengolahan \\
\hline 4. & D (Informan 4) & Kordinator Sirkulasi \\
\hline
\end{tabular}

b. Teknik Pengumpulan Data

Teknik pengumpulan data adalah teknik yang digunakan dalam memperoleh data yang dibutuhkan oleh peneliti teknik pengumpulan 
data penelitian yang digunakan dalam penelitian ini adalah melalui data primer yang meliputi:

1) Wawancara

Wawancara dapat diartikan sebagai percakapan antara dua orang atau lebih berlangsung antara narasumber dan pewawancara, wawancara dilakukan untuk menggali informasi yang dibutuhkan oleh peneliti. Teknik wawancara ini dilakukan secara langsung dengan pustakawan perpustakaan Universitas Muhammaiyah Mataram. Orang yang menjadi informan sebanyak 4 orang yang terdiri dari Kepala Perpustakaan, divisi layanan, koordinator pengolahan dan koordinator sirkulasi, wawancara dilakukan adalah wawancara struktur, dimana peneliti menggunakan pedoman wawancara yang telah tersusun secara sistematis dan lengkap untuk mengumpulkan data. Pedoman wawancara sangat diperlukan agar tidak menyimpan dari tujuan penelitian, pedoman wawancara juga tersusun berdasarkan teori yang berkaitan dengan masalah yang diteliti.

2) Observasi

Metode pengumpulan data melalui observasi lansung atau peninjauan secara cermat dan berlangsung pada objek dilapangan atau lokasi penelitian, Kriyantono (2010:97) menjelaskan observasi sebaga kegiatan mengamati secara langsung tanpa mediator sesuai objek untuk melihat dengan dekat kegiatan yang dilakukan oleh objek tersebut. Observasi yang digunakan peneliti dalam penelitian ini adalah pengamatan, yang di observasi adalah kegiatan dan penerapan kebijakan penyiangan penyiangan bahan pustaka di perpustakaan UMMAT.

3) Dokumentasi

\begin{abstract}
Dokumentasi dilakukan untuk pencarian data penunjang yang berhubungan dengan masalah penelitian yang diteliti dari berbagai sumber informasi, baik dari buku-buku atau sumber informasi lainnya, khususnya yang berhubungan dengan ilmu perpustakaan.
\end{abstract}

\section{Analisa Data}

Analisis data merupakan upaya mencari dan menata secara sistematis cacatan hasil observasi, wawancara dan lainnya untuk meningkatkan pemahaman peneliti tentang kasus yang diteliti dan menyajikan sebagai temuan kepada orang lain. Adapun tahapan dalam analisis data sebagai berikut:

a. Reduksi Data

Pada saat melkukan penelitian tentu hasil awal yang diperoleh masih sangat banyak, rumit dan sangat konpleks. Pada tahap reduksi data ini peneliti melkukan pemilihan pada data yang dianggap penting, kemudian mengkategorikan data yang diperoleh sesuai indicator penelitian dan peneliti membuang data-data yang tidak diperlukan. Hal ini dilakukan agar mempermudah penelitian dalam pengumpulan data selanjutnya serta mencari data bila diperlukan.

b. Display Data

Display data diartikan sebagai sekumpulan informasi tersusun yang memberikan kemungkinan adanya penarikan kesimpulan dan pengambilan tindakan. Dengan penyajian data, peneliti akan memahami apa yang sedang terjadi dan apa yang harus dilakukan berdasarkan pemahaman tentang penyajian data. Pada penelitian ini penulis mengumpulkan data dari informan di UPT Perpustakaan UMMAT, setelah pengumpulkan data tersebut, penulis kemudian mencoba memahami data yang telah didapat dari informan tersebut, kemudian 
penulis menyajikan data yang telah didapat dari informan, yang dimana datanya berupa kegiatan penyiangan bahan pustaka di UPT Perpustakaan UMMAT.

c. Verifikasi Data

Berdasarkan beberapa data yang telah dikumpulkan maka peneliti mencoba mengambil kesimpulan berdasarkan data tersebut. Kesimpulan itu masih sangat diragukan, akan tetapi dengan bertambahnya data makan kesimpulan itu lebih berkembang. Jadi kesimpulan senantiasa harus diferifikasi selama penelitian berlangsung. Pada penelitian ini penulis menarik kesimpulan dari hasil observasi dan wawancara terhadap informan, kemudian untuk lebih menguji kebenaran dari data tersebut, maka data tersebut diverifikasi sehingga penulis mendapat data yang akurat dan interpretasi data yang jelas.

\section{F. HASIL DAN PEMBAHASAN}

\section{Profil UPT Perpustakaan UMMAT}

Univeristas Muhammadiyah Mataram (UMMAT) didirikan pada tanggal 25 Juli 1980, dan mendapatkan status terdaftar berdasarkan SK Mindikbud RI No. 0171/O/1982. Sebagai Rektor pertama Drs. A. Karim Sahidu. Untuk mendukung keberlangsungan pelaksanaan tri dhrama perguruan tinggi, Pimpinan Univeristas Muhammadiyah Mataram memebentuk lembaga Perpustakaan sebagai salah satu sumber belajar, dan penyedia informasi bagi mahasiswa.

UPT Perpustakaan UMMAT terletak di jln. K.H Ahmad Dahlan No.1 Mataram yang berada di gedung Fakultas Kesehatan lantai 3 dan perpustakaan inilah yang menjadi perpustakaan pusat UMMAT sampai sekarang.

UPT Perpustakaan UMMAT memiliki luas \pm 180 $\mathrm{m}^{2}$ dan jumlah koleksi sebanyak \pm judul buku dengan jumlah \pm 13.643 eksemplar yang terdiri dari jenis koleksi buku, jurnal, majalah, dan karya ilmiah.

\section{Karakteristik Informan}

Informan pada penelitian ini adalah kepala UPT perpustakaan, pustakawan divisi bidang teknik layanan, 1 orang pustakawan pelaksana bagian pengolahan dan 1 orang pustakawan pelaksana bidang sirkulasi. Wawancara dilakukan melalui pendekatan dan perkenalan terlebih dahulu dengan para informan.

Setelah melalui perkenalan barulah kemudian diminta waktunya untuk bersedia diwawancara.

Table 2 Karakteristik Informan

\begin{tabular}{|c|c|l|}
\hline No. & \multicolumn{1}{|c|}{ Kode } & \multicolumn{1}{c|}{ Jabatan } \\
\hline 1. & $\mathrm{A}($ Informan 1) & Kepala Perpustakaan \\
\hline 2. & $\mathrm{~B}($ Informan 2) & Divisi Layanan \& Teknis \\
\hline 3. & $\mathrm{C}($ Informan 3) & $\begin{array}{l}\text { Pustakawan Pelaksana bagian } \\
\text { Pengolahan }\end{array}$ \\
\hline 4. & $\mathrm{D}($ Informan 4) & $\begin{array}{l}\text { Pustakawan Pelaksana bagian } \\
\text { Sirkulasi }\end{array}$ \\
\hline
\end{tabular}

Informan A yaitu kepala perpustakaan merupakan informan yang pertama kali diwawancarai oleh peneliti dengan perkenalan dan pendekatan terlebih dahulu.

Topik yang ditanyakan kepada informan A mengenai kebijakan penyiangan dan prosedur penyiangan koleksi perpustakaan. Informan B, C, dan D adalah pustakawan pelaksana maka topik yang dibahas yaitu mengenai proses pelaksanaan penyiangan (weeding) yang terdiri dari pedoman dalam melakukan penyiangan, waktu penyiangan, kewenangan melakukan penyiangan, kendala penyiangan, dan hasil dalam melakukan penyiangan.

Wawancara berlangsung secara informal. Wawancara dilakukan berdasarkan pada pedoman wawancara dengan teknik wawancara mendalah. Pelaksanaan wawancara dilakukan secara substansi. Suasana wawancara berlangsung alamiah, apa adanya, dan tidak diatur sedemikian rupa untuk tujuan tertentu, begitu juga dengan bagasa yang digunakan adalah bahasa informal. 
Isis wawancara berkembang sesuai dengan jawaban yang diberikan informan.

\section{Hasil dan Pembahasan}

Berdasarkan hasil wawancara dengan menggunakan pedoman wawancara, peneliti menyusun kerangka awal analisis sebagai acuan. Dengan kerangka awal ini, peneliti kemudia kembali membaca format wawancara dan melakukan coding, yaitu melakukan pemilihan data yang relevan dengan pokok pembicaraan dan menunjukkan hubungan antara bagian-bagian yang diteliti sehingga menghasilkan beberapa kategori. Peneliti dapat mengelompokkan delapan kategori yang berkaitan dengan penyiangan koleksi perpustakaan di UPT Perpustakaan UMMAT. Adapun delapan kategori tersebut adalah:

\section{Kebijakan Penyiangan (weeding)}

Kategori pertama yang diperoleh berdasarkan transkrip dari hasil wawancara dengan keempat informan adalah kebijakan penyiangan koleksi di UPT Perpustakaan UMMAT, maka peneliti mewawancari informan A (kepala UPT Pepustakaan UMMAT).

a. Kebijakan Penyiangan Koleksi Secara Tertulis.

Penyiangan koleksi yang dilaksanakan pada suatu perpustakaan tergantung pada kebijakan perpustakaan tersebut, dalam melakukan penyiangan koleksi perpustakaan memiliki kebijakan tertulis dan panduan dalam melakukan penyiangan yang nantinya akan menjadi patokan petugas/pustakawan dalam melaksanakan penyiangan.

P : Apakah perpustakaan memiliki kebijakan penyiangan koleksi secara tertulis dan setiap beberapa tahun sekali kebijakan tersebut ditinjau/dilakukan?

Berikut jawaban Informan A mengenai pertanyaan di atas:
A : "Kami tidak memiliki kebijakan secara tertulis, kami melakukan penyiangan disebabkan karena koleksi yang kami miliki belum pernah dilakukan penyiangan (weeding) selama perpustakaan di dirikan, oleh sebab itu tanpa adanya kebijakan secara tertulis, kami mempunyai landasan yang kuat dalam melakukan pernyiangan tersebut, seperti koleksi yang ada dirak sudah banyak yang kusam, tahun terbit sudah tua, dan ada juga sebagian koleksi yang rusak.

Berdasarkan pernyataan dari informan A di atas dapat diketahui bahwa UPT Perpustakaan UMMAT tidak memiliki kebijakan tertulis dalam melakukan penyiangan.

P : Apakah kebijakan penyiangan koleksi ditindak lanjuti dalam program tahunan?

Penyiangan di UPT Perpustakaan UMMAT tidak termasuk kedalam program kerja tahunan. Berikut jawaban informan A mengenai pertanyaan di atas:

A : “Tidak, penyiangan tidak termasuk kedalam program kerja tahunan perpustakaan”.

Berdasarkan pernyataan dari informan A di atas maka dapat diketahui bahwa kebijakan penyiangan koleksi di UPT Perpustakaan UMMAT tidak ditindak lanjuti dalam program kerja tahunan.

b. Cakupan Kebijakan Penyiangan

Sebelum melakukan penyiangan pustakawan perlu mengetahui apa saja yang mencakup kedalam kebijakan penyiangan koleksi, agar pustakawan lebih fokus dalam melakukan penyiangan.

P: Mencakup apa saja kebijakan penyiangan koleksi di perpustakaan?

Berikut jawaban informan A mengenai pertanyaan di atas:

A:"Kebijakan penyiangan koleksi perpustakaan mencakup, stok opname, perbaikan koleksi yang rusak, pelestarian bahan pustaka, penarikan/mengelurkan koleksi dari rak rusak dan sudah memiliki tahun terbit yang lama dan sudah tidak diminati oleh pemustaka”. 
Berdasarkan pernyataan yang diberikan informan A kepada peneliti dapat diketahui bahwa cakupan yang termasuk dalam kebijakan penyiangan koleksi UPT Perpustakaan UMMAT adalah stok opname, perbaikan koleksi yang rusak, pelestarian bahan pustaka, penarikan/mengelurkan koleksi dari rak rusak dan sudah memiliki tahun terbit yang lama dan sudah tidak diminati oleh pemustaka.

\section{c. Kewenangan Penyiangan}

Dalam melakukan penyiangan tentunya seorang pustakawan memiliki kewenangan, seperti yang di sampaikan informan berikut:

P: Siapa yang berwenang melakukan penyiangan? Apakah tugas penyiangan di serahkan kepada bagian perawatan dan pemeliharaan bahan pustaka atau ada tim khusus yang melakukannya?

Berikut pernyataan informan A mengenai pertanyaan di atas:

A : "Yang berwenang melakukan penyiangan adalah pihak perpustakaan tidak ada tim khusus dalam melakukan penyiangan, tapi sebelum melakukan penyiangan kami membentuk tim yang akan melakukan penyiangan dan dibantu oleh mahasiswa prodi D3 Perpustakaan karena pustakawan di UPT Perpustakaan UMMAT masih sedikit hanya 6 orang pustakawan”.

Berdasarkan pernyataan dari informan A di atas dapat diketahui bahwa yang berwenang melakukan penyiangan adalah pihak perpustakaan tidak ada tim khusus, dan di bantu oleh mahasiswa D3 perpustakaan.

\section{Prosedur Penyiangan (weeding)}

Kategori kedua yang diperoleh peneliti dari traksrip hasil wawancara dengan keempat informan adalah aturan atau prosedur dalam melaukan penyiangan koleksi perpustakaan UMMAT. Untuk mengetahui bagaimana prosedur penyiangan koleksi di UPT Perpustakaan UMMAT, maka peneliti mewawancari informan A (kepala perpustakaan).

P : Apakah perpustakaan memiliki aturan atau prosedur dalam melakukan penyiangan koleksi?

Berikut jawaban informan A mengenai pertanyaan di atas:

A : "kami belum mempunyai prosedur atau SOP secara tertulis dalam melakukan penyiangan ini, tapi sebelum kami melakukan penyiangan, kami breafing untuk mendiskusikan apa saja yang harus dilakukan dalam proses penyiangan, dalam hasil berafing tersebut yang harus kami lakukan dalam proses penyiangan adalah stock opname dan pelestarian bahan pustaka”.

Dari pernyataan informan A di atas dapat diketahui bahwa perpustakaan UMMAT tidak memiliki aturan atau prosedur tertulis dalam melakukan penyiangan koleksi.

\section{Alasan dan tujuan Penyiangan (weeding)}

Kategori yang ketiga dalam melakukan penyiangan koleksi diperoleh peneliti dari transkip hasil wawancara dengan keempat informan adalah alasan dan tujuan penyiangan. Penyiangan merupakan kegiatan pemilihan dan mengelurkan koleksi perpustakaan, dimana koleksi dinilai tidak bermanfaat lagi bagi perpustakaan dan dilakukannya penyingan tentunya memiliki tujuan bagi perpustakaan UMMAT, maka peneliti mewawancari informan 2 dan 3 .

a. Alasan penyingan

Penyiangn merupakan kegitan pemilihan terhadap koleksi perpustakaan dimana koleksi tersebut dinilai tidak dimanfaatkan lagi oleh pemustaka. Hal ini sesuai dengan pernyataan informan $\mathrm{B}$ dan $\mathrm{C}$ berikut.

$\mathrm{P}$ : Apa alasan kenapa penyiangan koleksi dilakukan?

Berikut jawaban dai informan $\mathrm{B}$ dan $\mathrm{C}$ mengenai pertanyaan di atas:

B : "karena koleksi di perpustakaan UMMAT tergolong tua, buku tersebut tidak pernah dipinjam lagi oleh pemustaka, ada edisi 
terbaru, buku rusak, koleksi kurang diminati, salinan atau duplikat terlalu banyak, dan rak terlalu penuh".

C : "Penyiangan dilakukan karena kondisi fisik seperti ertanya sudah kusam atau berubah warna kecoklatan, jilidannya terlepas, tingkat penggunaan koleksi berkurang, da nada juga halaman yang rusak".

Berdasarkan pernyataan informan B dan $\mathrm{C}$ di atas alasan dilakukan penyiangan adalah koleksi tersebut kurang diminati lagi oleh pemustaka, ada edisi terbaru, buku sudah kusam, jumlah eksemplar terlalu banyak, dan ada halaman buku yang sobek atau rusak".

\section{b. Tujuan penyiangan}

Tujuan dilakukannya penyiangan adalah untuk memenuhi kebutuhan pemustaka, agar koleksi perputakaan selalu up to date dan ruang koleksi perpustakaan dapat digunakan untuk buku-buku terbaru yang lebih dibutuhkan. Hal ini sesuai dengan penyataan dari informan $\mathrm{C}$ dan $\mathrm{D}$.

P : Apa tujuan dilakukannya penyingan?

Berikut jawaban dari informan $\mathrm{C}$ dan $\mathrm{D}$ mengenai pertanyaan di atas:

C : "kami memiliki program dan tujuan program tersubut untuk meng up to date koleksi-koleksi perpustakaan karena tujuan kedepan perpustakaan UMMAT ingin menambah koleksi baru, karena ruang koleksi terbatas dan rak koleksi tidak cukup untuk menampung lagi koleksi baru maka dilakukan penyiangan dengan kriteria-kriteria yang sudah ditentukan".

D : "Agar informasi koleksi tetap terjaga (up to date) memperbaiki koleksi-koleksi yang rusak, memisahkan koleksi-koleksi yang tidak layak dipakai, memiliki jumlah eksemplar yang banyak, tujuannya adalah agar koleksi di perpustakaan UMMAT tetap ter up date".

Berdasarkan pernyataan informan C dan D di atas dapat dinyatakan bahwa tujuan dilaksanakan penyiangan adalah untuk menghemat rungan dan koleksi perpustakaan tetap up to date".

\section{Pedoman dan Kriteria Penyiangan (weeding)}

Kategori keempat yang diperoleh peniliti dari trankip hasil wawancara dengan kedua informan adalah pedoman penyiangan. Dalam melakukan penyiangan tentunya harus memiliki pedoman dan kriteria agar tidak terjadi kesalahan dalam menyiangi koleksi. Maka peneliti mewawancarai informan B dan D.

a. Pedoman penyiangan

Dalam melakukan penyiangan harus memiliki pedoman agar pelaksanaan penyiangan kolesi tidak dilakukan secara asal asalan.

P : Apakah perpustakaan UMMAT memiliki pedoman dalam melakukan penyiangan?

Berikut jawaban informan $\mathrm{C}$ dan $\mathrm{D}$ mengenai pertanyaan di atas:

C : "Kalau pedoman khusus tidak ada, tapi kami menggunakan tahun terbit untuk melakukan penyiangan, tingkat kegunaan koleksi dan tingkat keusangan koleksi”.

D : "sampai saat ini kalau pedoman belum ada, hanya dilihat apakah informasinya sudah usang, koleksi yang tidak ada penggunanya, ada edisi terbaru, buku yang hilang bagiannya atau tidak lengkap, buku yang tidak sesuai dengan kebutuhan pemustaka".

Berdasarkan pernyataan di atas perpustakaan UMMAT tidak memiliki pedoman dalam melakukan penyiangan, perpustakaan UMMAT melakukan penyiangan menggunakan tahun terbit, tingkat kegunaan koleksi, tingkat keusangan koleksi, ada edisi terbaru, buku yang hilang bagiannya atau tidak lengkap.

b. Kriteria penyiangan

Sebelum melakukan penyiangan petugas terlebih dahulu menentuan kriteria-kriteria apa saja yang akan digunakan untuk mengkategorikan koleksi tersebut kedalam penyiangan.

P : Apa kriteria yang digunakan perpustakaan dalam melakukan penyiangan? 
Berikut jawaban informan B mengenai pertanyaan di atas:

B : "yang pertama kami menggunakan tahun terbit di bawah tahun 2000 an, misalnya belum tentu tahun lama itu di weeding seperti fakultas pertanian mereka banyak menggunakan koleksi tahun-tahun edisi lama, maka kami tidak melakukan weeding pada kolesi tersebut, dapat dilihat dari sejarah peminjaman di database sistem untuk mengetahui tingkat kegunaannya”.

Berdasarkan pernyataan di atas bahwa kriteria yang digunakan perpustakaan UMMAT dalam melakukan penyiangan adalah tingkat kegunaan koleksi, memiliki edisi baru, dan bahasa yang tidak dimengerti oleh pengguna.

\section{Waktu Penyiangan (weeding)}

Kategori kelima yang diperoleh peneliti dari transkip hasil wawancara dengan keempat informan adalah waktu pelaksanaan penyiangan dan waktu yang dibutuhkan dalam melakukan penyiangan. Waktu penyiangan tentunya dilakukan pada saat-saat tertentu, dan membutuhkan waktu yang lama untuk melakukan penyiangan tersebut. Maka peneliti mewawancari informan B dan C. dengan pertanyaan sebagai berikut.

a. Waktu penyiangan

P : kapan waktu dilakukannya penyiangan koleksi di perpustakaan UMMAT?

Berikut jawaban informan $\mathrm{B}$ dan $\mathrm{C}$ mengenai pertanyaan di atas:

B : "Walaupun kami belum mempunyai SOP dan kebijakan secara tertulis, penyiangan ini kami lakukan setiap 3 tahun sekali bersamaan dengan stock opname”.

C : "penyiangan dilakukan apabila pustakawan menemukan koleksi yang rusak di rak, dan penyiangan dilakukan 3 tahun sekali”.

Berdasarkan pernyataan informan B dan di atas dapat diketahui waktu dilakukan penyiangan koleksi di perpustakaan UMMAT adalah 3 tahun sekali. b. Waktu yang dibutuhkan dalam melakukan penyiangan

P : Berapa lama waktu yang dibutuhkan dalam melakukan penyiangan?

B : "Penyiangan membutuhkan waktu yang lama kurang lebih 10 hari karena ada penambahan koleksi dan kurangnya SDM dalam melakukan penyiangan".

C : "Waktu yang dibutuhkan dalam melakukan penyianya kurang lebih 10 hari".

Berdasarkan pernyataan informan B dan C di atas dapat diketahui waktu yang dibutuhkan dalam melaukan penyiangan koleksi di perpustakaan UMMAT adalah kurang lebih 10 hari.

\section{Kewenangan Penyiangan (weeding)}

Kategori keenam yang diperoleh peneliti dari transkip hasil wawancara dengan keempat informan adalah melakukan penyiangan, pencatatan koleksi yang rusak. Dalam melakukan penyiangan tentunya seorang pustakakawan memiliki kewenangan yang telah diketahui.

a. Yang berwenang melakukan penyiangan

$P$ : Siapan yang berwenang melakukan penyiangan? Apakah tugas penyiangan diserahkan kebagian perawatan dan pemeliharaan bahan pustaka atau ada tim khusus yang melakukannya?

Berikut jawaban informan B mengenai pertanyaan di atas.

B : "Yang berwenang melakukan penyiangan adalah keseluruhan dari pustakawan yang ada di perpustakaan UMMAT terlebih dahulu diketahui oleh kepala perpustakaan dan dibantu oleh mahasiswa semester 5 prodi D3 perpustakaan, kami tidak memiliki tim khusus dalam melakukan penyiangan tersebut”.

Berdasarkan pernyataan dari in forman B di atas dapat diketahui yang berwenang melakukan penyiangan koleksi di perpustakaan UMMAT adalah pertama diketahui terlebih dahulu oleh kepala perpustakaan UMMAT, dan kepala 
perpustakaan membentuk tim dan memilih koorditaor untuk mengontrol proses penyiangan, dan proses penyiangan ini dibantu oleh mahasiswa dari prodi D3 perpustakaan.

b. Pencatatan koleksi yang rusak

P : siapa yang melakukan pencatatan koleksi yang rusak, atau koleksi yang disiangi? Apakahperpustakaan memiliki petugas khusu yang melakukannya?

Berikut jawaban informan $\mathrm{C}$ dan $\mathrm{D}$ mengenai pertanyaan diatas:

C : "semua petugas bisa melakukan pencatatan koleksi yang akan dikeluarkan atau koleksi yang disiangi, perpustakaan tidak memiliki tim khusus untuk melakukannya karena kuranganya SDM".

D : "Kami tidak memiliki tik khusu untuk mencatat koleksi yang disiangi, karena kurangnya SDM di perpustakaan, jadi setiap petugas bebas melakukan semua tugas tersebut".

Berdasarkan penyataan dari informan C dan D di atas dapat diketahui bahwa perpustakaan UMMAT tidak memiliki tim khusus dalam melakukan pencatatan terhadap koleksi yang aka disiangi.

\section{Kendala Penyiangan (weeding)}

Kategori ke tujuh yang diperoleh peneliti dari transkip hasil wawancara dengan ketiga informan adalah kendala penyiangan koleksi. Seperti penyataan dari informan $\mathrm{C}$ dan $\mathrm{D}$ berikut:

$\mathrm{P}$ : Kendala apa yang sering dihadapi dalam melakukan penyiangan?

Berikut jawaban informan $\mathrm{C}$ dan $\mathrm{D}$ mengenai pertanyaan di atas:

C : "kendala yang dihadapi dalam melakukan penyiangan yaitu (1) kegiatan ini tidak ada dalam aturan tertulis sehingga tidak ada anggarannya (2) masih ada buku-buku yang sudah tidak layak pakai tetapi masih di butuhkan oleh pemustaka sehingga proses penyiangan ini terhambat karena harus memilih buku apa yang harus disiangi (3) kurangnya SDM sehingga tidak ada yang menangani khusus kegiatan penyiangan bahan pustaka”.
D : "Kendala yang dihadapi dalam melakukan penyiangan karena beberapa factor seperti pertama waktu untuk melakukan kegiatan penyiangan harus bersamaan dengan hari libur mahasiswa, karena apabila dilakukan pada saat aktivitas kuliah mahasiswa akan mempegaruhi penarikan/penyiangan bahan pustaka. Untuk itu perpustakaan harus mencari waktu yang pas untuk melakukan penarikan maupun stock opname".

Berdasarkan penyataan dari informan $\mathrm{C}$ dan D di atas dapat diketahui kendala yang dihadapi petugas dalam melakukan penyiangan adalah kendala waktu, dan kurang SDM yang menangai khusus kegiatan penyiangan.

\section{Hasil Penyimpanan Penyiangan (weeding)}

Kategori kedelapan yang diperoleh peneliti dari transkip hasil wawancara dengan keempat informan adalah penyimpanan hasil penyiangan koleksi perpustakaan UMMAT. Untuk mengetahui bagaimana penyimpanan terhadap koleksi yang disiangi maka peneliti mewawancari informan B dan D.

P : Bagaimana perpustakaan menyimpan koleksi hasil penyiangan tersebut?

Berikut penyataan Informan B dan D mengenai pertanyaan di atas:

B : "Hasil penyiangan kami tumpuk di sudut ruang baca pemustaka karena kami tidak memiliki gudang atau ruang khusus untuk menyimpan koleksi yang sudah di siangi”.

D : "hasil penyiangan di tumpuk di sudut rung baca kemudian hasil yang sudah di siangi di pindahkan kebagian administrasi untuk diputuskan apakah koleksi itu di hibahkan atau di musnahkan”.

Berdasrkan penyataan informan B dan D di atas dapat diketahui hasil penyiangan koleksi perpustakaan di tumpuk di sudut ruang baca pemustaka karena perpustakaan UMMAT tidak memiliki gudang atau ruang khusus untuk menyikpan koleksi yang sudah di siangi, kemudian koleksi yang ditumpuk di ruangan baca akan dipindahkan di ruang administrasi untuk di 
putuskan apakah koleksi tersebut mau dihibahkan atau di musnahkan.

\section{H. KESIMPULAN DAN SARAN}

\section{Kesimpulan}

Berdasarkan hasil penelitian yang diperoleh dari hasil wawancara langsung dari ke empat informan, maka dapat di simpulkan bahwa implemtasi kebijakan penyiangan koleksi di UPT Perpustakaan Universitas Muhammadiyah Mataram adalah sebagai berikut:

a. Perpustakaan Universitas Muhammadiyah Mataram hingga saat ini belum memiliki kebijakan secara tertulis dalam melakukan proses penyiangan koleksi perpustakaan.

b. Proses penyiangan di perpustakaan Universitas Muhammadiyah Mataram akan diadakan setiap tiga tahun sekali. Proses penyiangan perpustakaan UMMAT dilakukan bersamaan dengan proses Stock Opname.

c. Perpustakaan UMMAT tidak memiliki tim khusus untuk melakukan penyiangan, yang berwenang melakukan penyiangan koleksi adalah pihak perpustakaan dan dibantu oleh mahasiswa smester lima prodi D3 perpustakaan, dikarenakan kurangnya tenga pengelola perpustakaan.

d. Kendala yang dialami oleh perpustakaan Universitas Muhammadiyah Mataram dalam melakukan penyiangan diantaranya adalah, waktu untuk melakukan penyiangan maupun stok opname harus bersamaan dengan hari libur mahasiswa, masih banyak buku-buku yang sudah tidak layak pakai tetapi masih dibutuhkan oleh pemustaka sehingga proses penyiangan ini terhambat karena harus memilih buku apa yang harus di siangi, kurangnya tenga pengelola perpustakaan sehingga tidak ada yang menangani khusus proses penyiangan koleksi perpustakaan, dan kegiatan ini tidak ada dalam aturan tertulis sehingga tidak ada anggarannya.

\section{Saran}

Dari hasil kesimpulan masalah di atas terkait implementasi kebijakan penyiangan koleksi di UPT Perpustakaan Universitas Muhammadiyah Mataram, peneliti memberi saran atau masukan sebagai berikut:

a. Dalam melakukan penyiangan koleksi perpustakaan, perpustakaan Universitas Muhammadiyah Mataram hendaknya memiliki kebijakan secara tertulis dan disahkan oleh pihak yang berwenang, terutama kebijakan penyiangan (weeding) agar proses penyiangan bahan pustaka, memiliki konsep dan tujuan yang jelas dalam menyiangi bahan pustaka di perpustakaan Universitas Muhammadiyah Mataram.

b. Agar proses penyiangan koleksi perpustakaan bisa benar-benar terealisasi dengan baik, sebaiknya perpustakaan Universitas Muhammadiyah Mataram memiliki dana yang cukup untuk melakukan pengadaan koleksi dan anggaran khusus untuk pemeliharaan/penyiangan koleksi, dangan begitu penyiangan bisa dilaksanakan dengan maksimal.

c. Untuk merealisasikan proses penyiangan koleksi perrpustakaan dengan baik, alangkah baiknya perpustakaan Universitas Muhammadiyah Mataram memisahkan kegiatan stock opname dengan proses penyiangan. Dengan begitu proses tidak akan tertumpah tindih dan data pun tercampur aduk.

d. Sebagai perpustakaan perguruan tinggi yang mengedepankan kualitas, baik manajemen, pelayanan maupun koleksi, sebaiknya perpustakaan Universitas Muhammadiyah Matarammembuat data khusus (berita acara) tentang proses penyiangan bahan pustaka. 
Data tersebut bisa dijadikan patokan sebagai koleksi dan evaluasi untuk perbaikan kegiatan penyiangan bahan pustaka dan juga kebutuhan-kebutuhan lainnya.

\section{DAFTAR PUSTAKA}

Almah, Hildawati. 2012. Pemilihan dan Pengembangan Koleksi Perpustakaa, Makassar: Alauddin University Pres.

Dianel J. Young, Get to Efective Weedin, http//www.tsl.state.tx.us., diakses pada tanggal 4 November 2019, jam 11.30 Wita

Evan, G. Edward, and Margaet R. Zarnosky. 2000. Developing Library and Information Center Collection. $4^{\text {th }}$ ed: London: Libraries Unlimited

http://www.libsuccess.org/index.php, Weeding Library Collection, diakses pada tanggal 5 November 2019 jam 09:00

Ibrahim Andi. 2015. Pengantar Ilmu Perpustakaan dan Kearsipan. Cet. 3, Jakarta: Gunadarma Ilmu

Kohar, Ade. 2009. Teknik Kebijakan Pengembangan Koleksi, Jakarta: Perpustakaan Nasional RI

Masridah, Lelis. 2009. Kebijakan Penyiangan Koleksi di Badan Perpustakaan Provinsi Daerah Istimewah Yogyakarta. Yogyakarta: UIN Sunan Kalijaga.

Mauglib's Weblog. Analisis Koleksi Perpustakaan, Penyiangan dan Evaluasi, http//maunglib.wordpress.com, diakses pada 5 November 2019 jam 09:00.

Sugiyono, 2010. Metode Penelitian Kualitatif, Kuantitatif dan R\&D. Bandung: Alfabeta

Sutarno, NS. 2006. Manajemen Perpustakaan: Suatu Pendekatan Praktis, Jakarta: Sagung Seto

Tim Reality. 2008. Kamus Terbaru Bahasa Indonesia. Surabaya: Reality Publisher.

Yunus Winoto, 2004. Penyiangan (weeding) Bahan Pustaka: Sebuah Tinjauan Teoritis" Journal Info PERSADA; Media Informasi Perpustakaan Universitas Sanata Dharma, Vol.2/No.2/Agustus2004, H. 11. 